\title{
Sunburn incidence of apples is affected by rootstocks and fruit position within the canopy but not by fruit position on the cluster
}

\author{
Racskó, J. ${ }^{1}$, Szabó, Z. ${ }^{2}$, Miller, D.D. ${ }^{1}$, Soltész, M. ${ }^{3}$ \& Nyéki, J. ${ }^{2}$ \\ ${ }^{1}$ Department of Horticulture and Crop Science, The Ohio State University, Ohio Agricultural Research \\ and Development Center, 1680 Madison Ave., Wooster, OH 44691, USA \\ ${ }^{2}$ Institute for Research and Development, University of Debrecen, 138 Böszörményi St., Debrecen 4032, Hungary \\ ${ }^{3}$ Department of Fruit Production, Faculty of Horticulture, College of Kecskemét, \\ 1-3 Erdei Ferenc square, Kecskemét 6000, Hungary
}

\begin{abstract}
Summary: Authors investigated sunburn incidence of apples on the combinations of three different growth inducing rootstocks (M.9, MM.106 and seedling) and five varieties ('Smoothee', 'Golden Reinders', 'Granny Smith', 'Gloster' and 'Jonagold Jonica'). Symptoms were classified as sunburn browning, sunburn necrosis and photooxidative sunburn. The frequency of symptoms was recorded at various parts of the canopy (N, E, W, S, and lower canopy, upper canopy) and on the cluster (terminal, lateral). Cultivar susceptibility varied between 0.30 and $5.65 \%$ on M.9 rootstock, 'Granny Smith' seemed to be the most susceptible cultivar whereas relatively low percentage of damaged fruit was observed for 'Gloster'. On MM.106 and seedling rootstocks, damage level was significantly lower than on M.9. Remarkable differences were not observed in the share of the three sunburn types between cultivars. The most common symptom observed was sunburn browning. Far less fruit was affected by sunburn necrosis and photooxidative sunburn. Photooxidative sunburn symptoms were not found on 'Granny Smith' and 'Gloster' fruits on MM.106 rootstock. Latter cultivar did not show sunburn necrosis symptoms either. With increasing growing vigor of the rootstocks the share of sunburn browning increased. Fruits with sunburn symptoms were found in a great majority on the W quadrant of the trees. This was true for all cultivars. Remarkable differences in the location within the canopy of affected fruits between the three types of sunburn were not observed. Specific distribution of sunburned fruit was observed along the vertical axis of the canopy, too. Most of the damaged fruit were found in the upper canopy. This is particularly true for trees on vigorous stocks such as MM.106 and seedling. On M.9 rootstock, depending on cultivars 5.9 to $38.9 \%$ of sunburned fruit was located in the lower canopy. Most common symptom in the lower canopy was the sunburn browning, however symptoms of sunburn necrosis were not found at lower canopy level. Low rate of photooxidative sunburn was observed such lower canopy conditions. Sunburn incidence was very similar on king or side fruit. Significant differences were not found in the share of each sunburn types between fruit positions on the cluster. This was not influenced by rootstocks either.
\end{abstract}

Key words: Malus domestica Borkh., apple, sunburn, terminal fruit, king fruit, lateral fruit, fruit position, canopy, sunburn browning, sunburn necrosis, photooxidative sunburn

\section{Introduction}

Sunburn is a physiological disorder of apple fruit caused by excessive heat and/or solar radiation (Barber and Sharpe, 1971; Schrader et al., 2001; 2003a; Wünsche et al., 2001; 2004; Racskó et al., 2005c). It severely affects fruit finish and marketing quality (Barber and Sharpe, 1971; Racskó et al., 2005b, Schrader et al., 2008; 2009), and thus causing serious problems in several major apple growing regions of the world (Bergh et al., 1980; Simpson et al., 1988; Warner, 1997). Sunburned fruit can be more sensible to secondary fruit infection by fruit rot pathogens (Holb, 2003, 2004) Sunburn costs the apple industry hundreds of millions of dollars annually. For instance, in Washington State, which produces over half of the U.S. apple crop, sunburn is usually the major source of cullage with losses averaging 10\% annually (Schrader et al., 2008). In warmer climates such as
South Africa (Bergh et al., 1980; Wand and Gindaba, 2005; Wand et al., 2006), Chile (Yuri et al., 1996) and Australia (Middleton et al., 2002; Mackay, 2009), losses can often be even three or four times higher than in Washington State.

Based on the conditions of the formation of the symptoms, there are three different types of sunburn distinguished in apples; sunburn necrosis, sunburn browning and photooxidative sunburn. The specific conditions at which sunburn necrosis and sunburn browning occur were defined by Schrader et al. (2001, 2003b), and the conditions of the formation of photooxidative sunburn have recently been determined by Felicetti (2003) and Felicetti and Schrader (2008). The first type, sunburn necrosis, appears after high fruit surface temperature $-\mathrm{FST}\left(\sim 52^{\circ} \mathrm{C}\right)$ causing thermal cell death with complete inactivation of the photosynthetic system. Symptoms occur within 1-4 days after irradiation as dark brown or blackish, single necrotic 
spots on the fruit surface exposed to the sun. The second type, called sunburn browning, is caused by concomitant exposure to high FST ( 45 to $49^{\circ} \mathrm{C}$ depending on cultivar) and UV-B radiation. In this case, the excess solar energy results in degradation of the pigmentation in the affected area, but does not result in cell death. Sunburn browning usually has symptoms with yellow, brown or dark tan discoloration on the exposed side of the fruit. The third type, photooxidative sunburn, is distinctly different from sunburn necrosis and sunburn browning due to the special conditions of its formation. It requires only visible light (infrared radiation) and affects shaded (non-acclimated) apples that are suddenly exposed to solar radiation. The initial symptoms of photooxidative sunburn can develop under $31^{\circ} \mathrm{C} \mathrm{FST}$ and can be detected within 24 hours as bleaching or whitening of the sun-exposed skin surface. With continued exposure to sunlight, the photobleached area can easily turn brown and cells become necrotic.

The aim of this research was assess the ratio of each sunburn type at different positions of the canopy and on the cluster. Assessments were made on three different growth inducing rootstocks in order to get information how growing vigor affects sunburn incidence.

\section{Materials and methods}

\section{Experimental site and plant material}

Field observations were made in an experimental apple orchard in Nagykutas, Western Hungary. 'Braeburn Hillwell', 'Golden Delicious', 'Granny Smith', 'Red Elstar' and 'Royal Gala' cultivars were chosen. Trees were grafted onto M.9, MM.106 and seedling rootstocks and planted in 1996 at a spacing of $3.6 \times 0.5 \mathrm{~m}$ and trained as super spindel. All trees were planted in N-S row orientation with 40 trees per cultivar replication. In the orchard, standard cultural practices (plant protection, winter pruning and fertilization) were followed based on local recommendations, irrigation was not applied. No growing practices influencing the susceptibility of cultivars to sunburn, such as summer pruning, were applied.

\section{Sunburn assessments}

Sunburn assessments were done on the combination of three rootstocks and five cultivars during 2 consecutive years, in 2006 and 2007 except for the observations on seedling rootstock because trees on this rootstock were cut off in the spring of $2008.4 \times 30=120$ fruit per accession were randomly selected on the tree and assessed in the field at full maturation of fruit. For sunburn assessments, fruit were sorted into four classes; one class was for undamaged fruit showing no symptoms of excessive heat and/or solar radiation, and three classes for the three different types of sunburn according to the Schrader-McFerson classification (Schrader et al., 2003a): sunburn browning, sunburn necrosis and photooxidative sunburn. Those fruit were considered to be affected by sunburn browning which showed yellow or light brown skin discoloration on the sun-exposed side of the fruit. Fruit with sunburn necrosis had dark brown or black burned spots while as a result of photobleaching, photooxidative sunburn had symptoms of whitish spots on the fruit surface exposed to the sun. The absolute and relative frequencies of damaged/undamaged fruit were recorded. Records were kept on the position of fruit examined on the tree (i.e. the N, E, S, W quadrants of the tree and the lowerupper canopy location) and on the position of the fruit on the cluster (i.e. terminal or lateral).

\section{Data analyses}

Data analysis for sunburn incidence was performed using SAS for Windows (Release 9.1., SAS Institute Inc., Cary, NC, USA). Statistical significance was defined at $p<0.05$ level.

\section{Results}

\section{Sunburn incidence on different rootstocks}

Cultivar susceptibility varied between 0.30 and $5.65 \%$ in average on M.9 rootstock (Fig. 1). 'Granny Smith' (5.65\%) seemed to be the most susceptible cultivar followed by 'Smoothee' (4.45\%), 'Golden Reinders' (3.90\%) and 'Jonagold Jonica' (2.91\%). Relatively low percentage of damaged fruit was observed for 'Gloster' $(0.30 \%)$. On MM.106 rootstock, damage level was significantly lower than on M.9. No damage was found for 'Smoothee' and all the other cultivars had $<2 \%$ damage. Damage level further decreased with increasing vegetative vigor of the rootstocks; on seedling stock, fruits of 'Golden Reinders' and 'Jonagold Jonica' showed sunburned symptoms only. The incidence was less than $1 \%$.

Remarkable differences were not observed in the share of the three sunburn types between cultivars (Fig. 1). The most common symptom observed was sunburn browning. Far less fruit was affected by sunburn necrosis and photooxidative sunburn. Photooxidative sunburn symptoms were not found on 'Granny Smith' and 'Gloster' fruit. Latter cultivar did not show sunburn necrosis symptoms either. With increasing growing vigor of the rootstocks the share of sunburn browning increased.

\section{Sunburned fruit position within the canopy}

Fruits with sunburn symptoms were found in a great majority on the $\mathrm{W}$ quadrant of the trees. This was true for all cultivars. For instance, damage distribution of 'Smoothee' cultivar within the canopy is shown on Fig. 2. A little percentage of sunburned fruit was found in the $S$ quadrant of the trees on M.9 rootstock only. On MM.106 and seedling rootstocks, only the $\mathrm{W}$ side of the tree had sunburned fruits. 

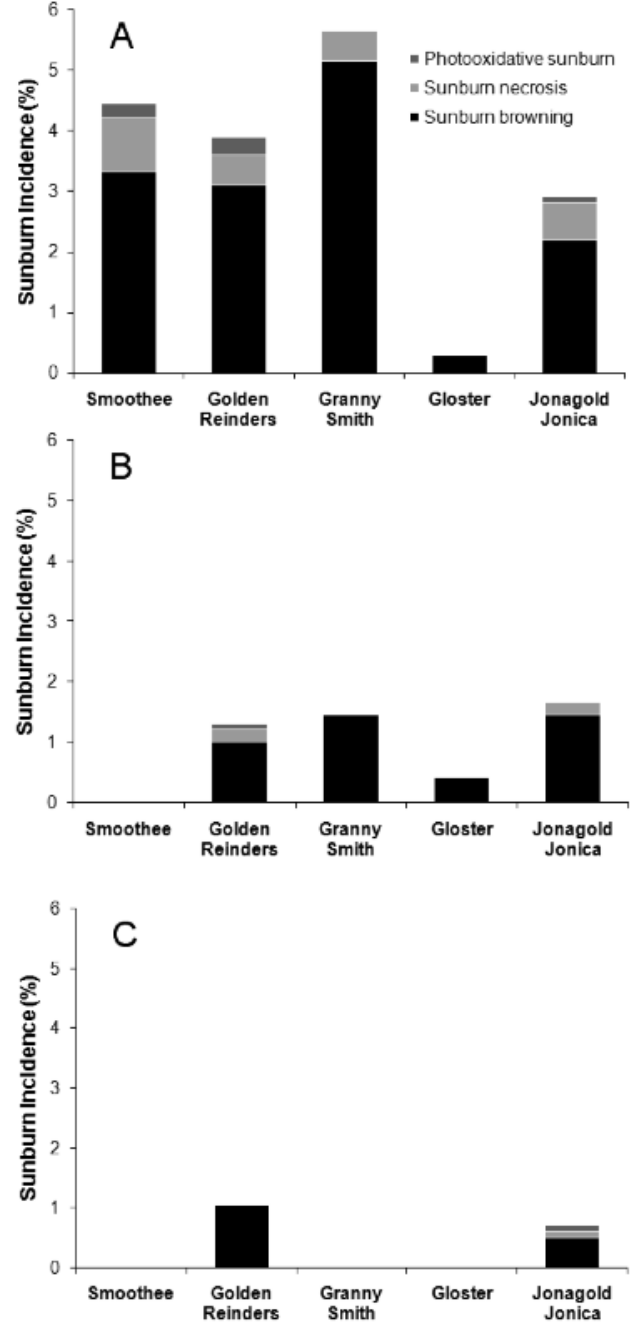

Fig. 1. Sunburn incidence of five apple cultivars and the share of each type of sunburn on M.9 (A), MM.106 (B) and seedling (C) rootstocks at harvest. Data are based on the average of 2006 and 2007.

Remarkable differences in the location of affected fruits between the three types of sunburn were not observed.

Specific distribution of sunburned fruit was observed along the vertical axis of the canopy too (Fig. 3). Most of the damaged fruit were found in the upper canopy. This is particularly true for trees on vigorous stocks such as MM.106 and seedling. On M.9 rootstock, depending on cultivars 5.9 to $38.9 \%$ of sunburned fruit was located in the lower canopy. 'Smoothee' had the greatest share of damaged fruit located in the lower canopy. Most common symptom in the lower canopy was the sunburn browning, however, symptoms of sunburn necrosis were not found at lower canopy level (Data not shown). Low rate of photooxidative sunburn was observed such lower canopy conditions.

\section{Sunburned fruit position on the cluster}

Distributions of king and side fruits for all rootstockcultivar combinations are shown on Fig. 4. Rootstocks did not affect king-side fruit ratio of the cultivars. Rootstock, however, did have a negative effect on fruit set, i.e. fruit

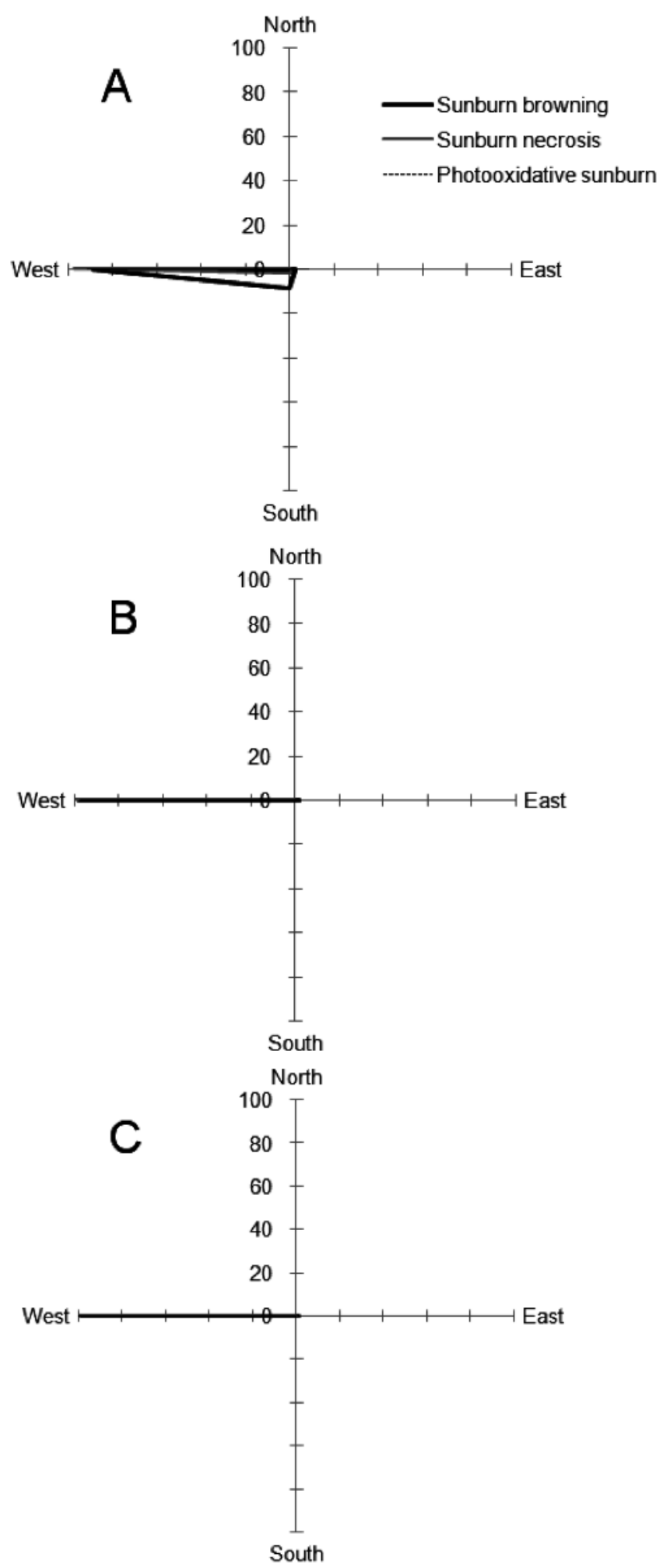

Fig. 2. The proportion of the three sunburn types of 'Smoothee' cultivar on M.9 (A), MM.106 (B) and seedling (C) rootstocks at each quadrant (N, E, S, and W) of the canopy. Data are based on the average of 2006 and 2007.

number per 100 cluster. Significant differences in the ratio of king and side fruit were not found in the positions of fruit within canopy. Fig. 5 shows that sunburn incidence was very similar on king or side fruit. Significant differences were not found in the share of each sunburn types between fruit 

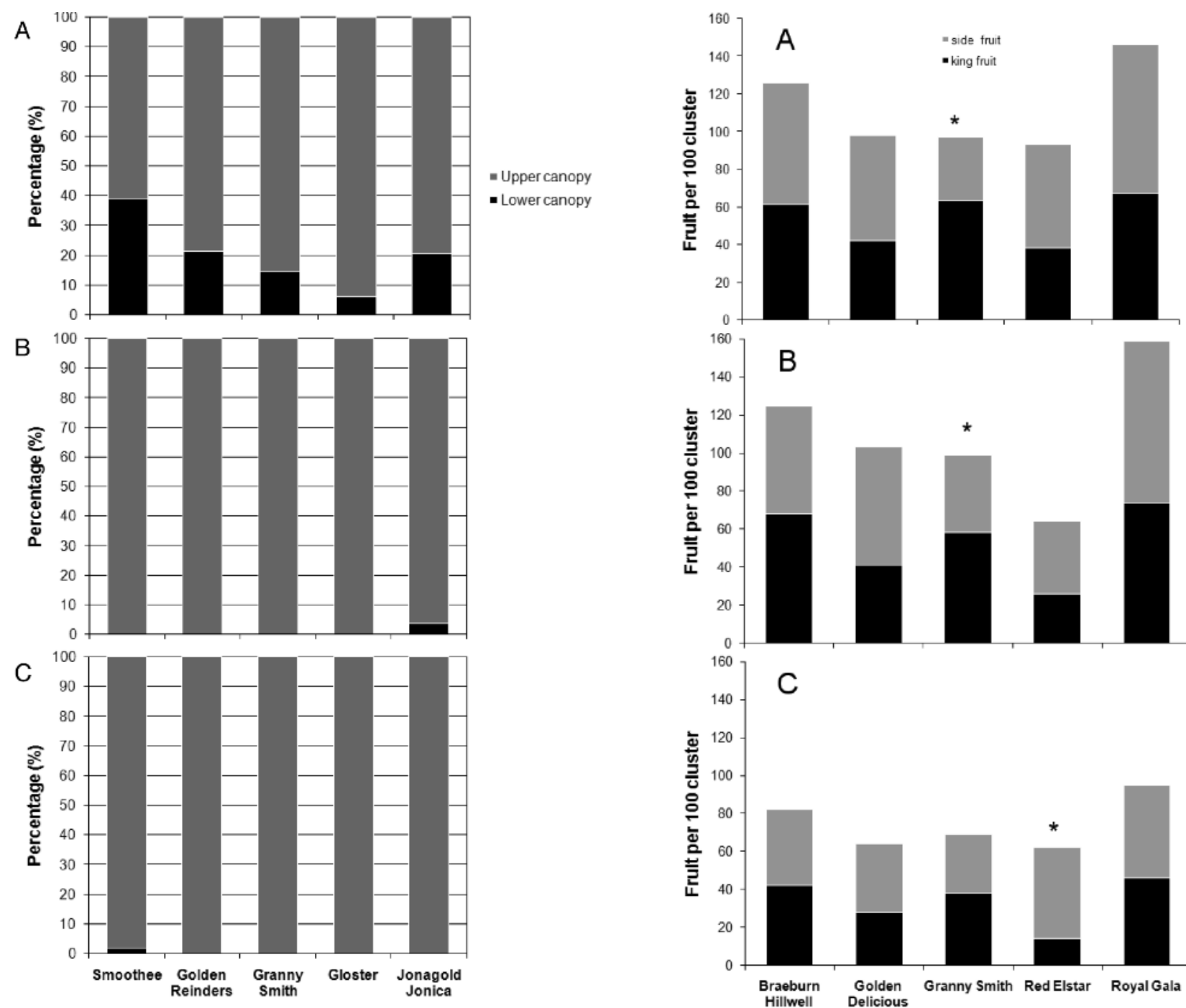

Fig. 3. The share of sunburned fruit located in the upper or lower canopy on M.9 (A), MM.106 (B) and seedling (C) rootstock. The ratio of sunburned fruit was significantly greater for the upper canopy at $\mathrm{P}<0.05$ level. Data are based on the average of 2006 and 2007.

positions on the cluster (Data not shown). In other words, sunburn browning, sunburn necrosis or photooxidative sunburn symptoms could occur either on king fruit or side fruit with the same probability. This was not influenced by rootstocks either.

\section{Discussion}

\section{Cultivar susceptibility to sunburn}

Results presented here demonstrate that the levelof sunburn damage varies with apple cultivars and sunburn symptoms have a special spatial distribution within the canopy. Similarly to our earlier results (Racskó et al., 2005a, 2008), we found that 'Golden Delicious', 'Smoothee' (i.e. 'Golden Delicios' clone) 'Granny Smith', 'Jonagold Jonica'

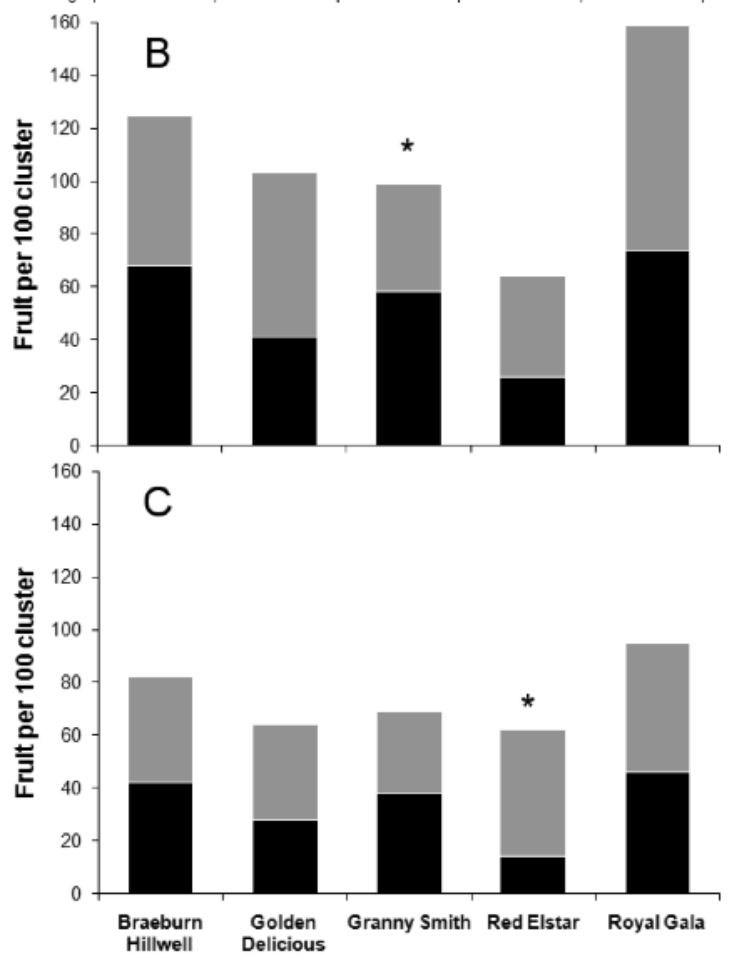

Fig. 4. Distributions of king and side fruits on the clusters of five apple cultivars on M.9 (A), MM.106 (B) and seedling (C) rootstocks at harvest. Data are based on the average of 2006 and 2007. * indicates significant differences in fruit set between king and side fruit.

are susceptible, while 'Gloster' is moderately susceptible to sunburn. This is in accordance with several other observations from various parts of the world. Mackay (2009) reported 30$70 \%$ sunburn damage in 'Granny Smith' apples indicating its strong susceptibility in Australian conditions. 'Granny Smith' seemed to be susceptible in California too where 50\% damage can be calculated annually in unprotected cultivation systems (Sibbett et al., 1991). In South Africa, 'Granny Smith' and 'Fuji' are the most susceptible cultivars while 'Pink Lady' and 'Braeburn' less so (Wand and Gindaba, 2005). Schrader (2009) found that 'Fuji' was moderately susceptible in Washington. Arndt (1992) reported 50\% damage in 'Jonagold' cultivar in the U.S. Soltész and Szabó (1998) mentioned in a cultivar description that 'Charden', 'Elstar', 'Granny Smith', 'Jonagold' and 'Mutsu' cultivars are susceptible to sunburn in Hungarian conditions. Later, Szabó (2004) confirmed the strong susceptibility of 'Jonagold' and 'Mutsu' cultivars. Van den Ende (1999) reported 'Granny 


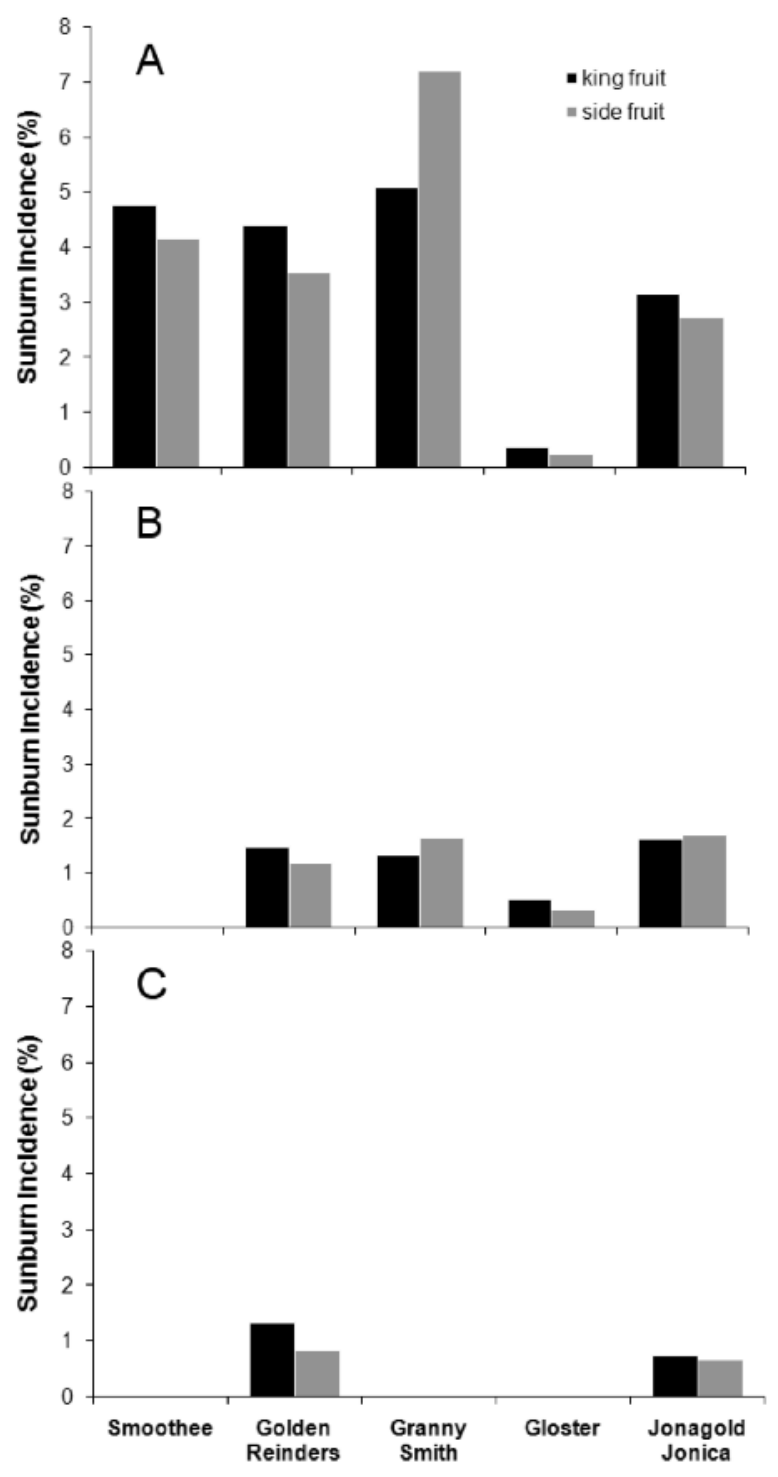

Fig. 5. Percentage of fruit affected by sunburn in terminal or lateral position of the cluster on M.9 (A), MM.106 (B) and seedling (C) rootstocks at harvest. Data are based on the average of 2006 and 2007. No significant difference was found in sunburn incidence between king and side fruit on all rootstock-cultivar combinations.

Smith', 'Fuji', 'Braeburn' and 'Jonagold' cultivars tend to burn more than 'Red Delicious', 'Golden Delicious' or 'Gala' in Australian conditions.

\section{Rootstock effects on cultivar susceptibility and on sunburn damage}

Rootstocks greatly influence tree vigor and thus canopy which is able to provide shade against excessive solar radiation. Therefore, they have a great indirect effect on sunburn damage of apple fruit.

Sunburn has become worse since the industry began growing smaller trees on dwarfing rootstocks. One of the major weaknesses of the presently available dwarf rootstocks is that they do not have extensive root zone and therefore they root close to the ground level, so more sensitive to drought stress. They experience generally higher water stress because of higher transpiration demand. Trees on dwarfing stocks bear more fruit per leaf area than vigorous stocks and that the presence of fruit increases transpiration under stress conditions, in combination with greater root resistance, i.e. water potential (Olien and Lakso, 1984). Decreased water supply to trees on dwarfing stocks may be a component of the dwarfing mechanism (Tubbs, 1973).

Observations of Wünsche et al. (2004), Racskó et al. (2005c) and Coster (2009) clearly demonstrate that trees on dwarfing stocks (e.g. M.9) with relatively open canopies are, compared to semi-vigorous (e.g. MM.106) or vigorous stocks (e.g. seedling), more susceptible to sunburn injury because the fruit is more exposed to sunlight. Increased sunburn damage on trees on rootstocks with low vigor was reported by van den Ende (1999), too. Bergh et al. (1980) reported less damage on the vigorous M.793 rootstock with 'Starking' cultivar compared to MM.106 (semi-vigorous) and M.26 (dwarf) stocks. Middleton et al. (2002) observed twice of the sunburn damage on trees on MM.106 rootstock compared to Northern Spy or MM.104 stocks. Benegas et al. (2006) compared M.7, M.9 and MM.111 rootstocks and found significantly greatest proportion of sunburned fruit on M.9 stock, negatively correlated with crop load.

\section{Fruit position within the canopy}

Fruits exposed to direct sunlight have greater chance to sunburn (Wünsche and Lakso, 2000). Sunburned fruit were found mostly in the southern and western quadrants of the canopy in the northern hemisphere indicating that these parts received the greatest irradiation (Allmendinger et al., 1943). The most exposed surfaces of fruits, i.e. the greatest percentage of sunburned fruit, faced to north and west in the southern hemisphere in Australia (Atkinson, 1971; van den Ende, 1999; Coster, 2009), Chile (Yuri et al., 2004, 2008), New Zealand (Atkinson, 1971; Wünsche et al., 2001) and South Africa (Bergh et al., 1980). That fact that fruit are most frequently damaged on the southwestern (northern hemisphere) or northwestern surface (southern hemisphere) (Bergh et al., 1980) indicates that fruit damage occurs during the afternoon hours.

Fruits located in the periphery or in the top of the tree are more prone to sunburn than those located in the bottom or inside the canopy (Allmendinger et al., 1943; Wilton, 1994; Racsko et al., 2005c) regardless of the training system used (Benegas and Rodriguez, 2007). This is particularly true for weaker growing cultivars such as 'Braeburn' which often "runt" out towards the tree top leading to severe sunburn in the upper tree (Wilton, 1994).

Saudreau et al. (2007) pointed out that exposed fruits have higher temperatures and higher temperature gradient compared to those of shaded. Generally, the top of the fruit has a higher exposure (radiant heating) then the bottom (convective heating). This explains that sunburn symptoms, particularly sunburn necrosis, can often be found on the shoulder of the fruit exposed to the sun. 


\section{References}

Allmendinger, D.F., Overley, F.L. \& O'Neill, W.J. (1943): Experts study on apple sunburn - Is fluorine spray more to blame than lead arsenate? Better Fruit, 38 (1): 6-7.

Arndt, H. (1992): Apple shading to reduce heat damage. Tree Fruit Leader, Vol. 1.

Atkinson, J.D. (1971): Sunburn, In: Atkinson, J.D. (ed.), Diseases of tree fruits in New Zealand. A.R. Shearer, Govt. Printer, Wellington, New Zealand, 168-169.

Barber, H.N. \& Sharpe P.J.H. (1971): Genetics and physiology of sunscald of fruits. Agric. Met., 8: 175-191.

Benegas, R.M.D. \& Rodríguez, A. (2007): Factores que afectan el porcentaje de fruta asoleada en manzanos cv. Fuji en el Alto Valle de Río Negro y Neuquén [Factors affecting the percentage of sunburn in Fuji apple in the High Valley of Río Negro and Neuquén]. Rev. Investig. Agropec. 36 (1): 131-146. (In Spanish with English summary)

Benegas, R.M.D., Rodríguez, R. \& Rodríguez, A. (2006): Distribución lumínica en diferentes combinaciones portainjerto/ variedad en manzana cv. Mondial Gala y su efecto sobre la calidad de la fruta y parámetros vegetativos [Light distribution in different rootstock-variety combinations of Mondial Gala apple trees and its effect on fruit quality and vegetative parameters]. Rev. Investig. Agropec. 35 (2): 53-69. (In Spanish with English summary)

Bergh, O., Franken, J., Zyl, E.J., van Kloppers, F. \& Dempers, A. (1980): Sunburn on apples - Preliminary results of an investigation conducted during the 1978/79 season. Deciduous Fruit Grower 30 (1): 8-22.

Coster, S. (2009): Sunburn on apples. Tree Fruit, November: 16.

Felicetti, D.A. (2003): Characterization of a third type of apple sunburn caused by sudden exposure of shaded apples to sunlight. M.S. Thesis, Washington State University, Pullman. 28. pp.

Felicetti, D.A. \& Schrader, L.E. (2008): Photooxidative sunburn of apples: Characterization of a third type of apple sunburn. Int. J. Fruit Sci., 8 (3): 160-172.

Holb, I. J. (2003): The brown rot fungi of fruit crops (Monilinia spp.). I. Important features of their biology. Int. J. Hortic. Sci., 9 (3-4): 23-36.

Holb, I. J. (2004): The brown rot fungi of fruit crops (Monilinia spp.). III. Important features of their disease control. Int. J. Hortic. Sci., 10 (4): 31-48.

Mackay, K. (2009): Reduce sun damage. Tree Fruit, September: 19.

Middleton, S., McWaters, A., James, P., Jotic, P., Sutton, J. \& Campbell, J. (2002): The productivity and performance of apple orchard systems in Australia. Compact Fruit Tree, 35 (2): 43-47.

Olien, W.C. and Lakso, A.L. (1984): A comparison of the dwarfing character and water relations of five apple rootstocks. Acta Hort. 146: 151-158.

Racskó, J., Midgley, S.J.E., Lakatos, L., Miller, D.D., Soltész, M., Szabó, Z., Nyéki, J. \& Costa, C. (2008): A survey of cultivar/ rootstock and orchard management factors influencing the incidence of sunburn damage on apple fruit in Hungary and South Africa. $9^{\text {th }}$ Int. Symp. on Integrating Canopy, Rootstock and Environmental Physiology in Orchard Systems. Geneva, NY, USA. Abstracts, 134. p.
Racskó, J., Nagy, J., Szabó, Z., Major, M. \& Nyéki, J. (2005a): The impact of location, row direction, plant density and rootstock on the sunburn damage of apple cultivars. Int. J. Hort. Sci., 11 (1): 19-30.

Racskó, J., Szabó, Z. \& Nyéki, J. (2005b): Importance of the supraoptimal radiance supply and sunburn effects on apple fruit quality. Acta Biol. Szegediensis, 49: 111-114.

Racskó, J., Szabó, Z., Nyéki, J., Piskolczi, M., Soltész, M. \& Farkas, E. (2005c): A klímaváltozás, az alanyhasználat és a technológiai megoldások szerepe az alma napégéses károsodásában. [The role of climate change, rootstock use and choice of technology in sunburn damage of apple]. AGRO-21 Füzetek, 39: 35-54. (In Hungarian with English summary)

SAS Institute Inc. (2002-2003): SAS Procedures Guide, Version 9.1.Cary, NC, USA.

Saudreau, M., Sinoquet, H., Santin, O., Marquier, A., Adam, B., Longuenesse, J.J.,Guilioni, L. \& Chelle, M. (2007): A 3D model for simulating the spatial and temporal distribution of temperature within ellipsoidal fruit. Agric. Forest. Met., 147: 1-15.

Schrader, L.E. (2009): Sunburn of apples: Causes and suppression of sunburn damage. ASHS Annu. Conf., St. Louis, MO, USA. Abstract in HortScience, 991.

Schrader, L.E., Zhang, J. \& Duplaga, W.K. (2001): Two types of sunburn in apple caused by high surface (peel) temperature. Plant Health Progress, online doi:10.1094/PHP-2001-1004-01-RS.

Schrader, L.E., Sun, J., Felicetti, D., Seo, J-H., Jedlow, L. \& Zhang, J. (2003a): Stress-induced disorders: effects on apple fruit quality. Washington Tree Fruit Postharvest Conf., Wenatchee, WA. 7. pp. Online at http://postharvest.tfrec.wsu.edu/PC2003A.pdf

Schrader, L.E., Zhang, J. \& Sun, J. (2003b): Environmental stresses that cause sunburn of apple. Acta Hort., 618: 397-405.

Schrader, L.E., Sun, J., Zhang, J., Felicetti, D.A. \& Tian, J. (2008): Heat and light induced apple skin disorders: causes and prevention. Acta Hort., 772: 51-58.

Schrader, L., Zhang, J., Sun, J., Xu, J., Elfving, D.C. \& Kahn, C. (2009): Postharvest changes in internal fruit quality in apples with sunburn browning. J. Amer. Soc. Hort. Sci., 143: 148-155.

Sibbett, G.S., Micke, W.C., Mitchell, F.G., Mayer, G. \& Yeager, J.T. (1991): Effect of a topically applied whitener on sun damage to Granny Smith apples. Calif. Agric., 45 (1): 9-10.

Simpson, J., Rom, C.R. \& Patterson, M. (1988): Causes and possible controls of sunburn on apples. Good Fruit Grower 39 (2): 16-17.

Soltész, M. \& Szabó, T. (1998): Alma [Apple] p. 119-155. In: Soltesz, M. (ed.): Gyümölcsfajta-ismeret és -használat. Mezőgazda Kiadó, Budapest.

Szabó, T. (2004): Ültetési anyag-, alany- és fajtaválasztás, a szaporítóanyag minőségi követelményei, pp. 49-82. (In: Inántsy, F., Balázs, K. (eds.): Integrált növénytermesztés - Alma.) Agroinform Kiadó, Budapest.

Tubbs, F.R. (1973): Research fields in the interaction of rootstocks and scions in woody perennials. Hort. Abstracts, 43: 247-253, 325-335.

Van den Ende, B. (1999): Sunburn management. Compact Fruit Tree, 32 (1): 13-14.

Wand. S.J.E. \& Gindaba, J. (2005): Controlling sunburn: What are the options? South African Fruit Journal Oct/Nov: 24-26.

Wand, S.J.E., Theron, K., Ackerman, J. \& Marais, S.J.S. (2006): Harvest and post-harvest apple fruit quality following applications of kaolin particle film in South African orchards. Scientia Hort., 107: 271-276. 
Warner, G. (1997): Sunburn is a hot topic in orchards of Washington. Good Fruit Grower, 48: 22-23.

Wilton, J. (1994): Managing the sunburn problem. Orchardist 67 (10): 19-21.

Wünsche, J.N., Greer, D.H., Palmer, J.W., Lang, A. \& McGhie, T. (2001): Sunburn - The cost of a high light environment. Acta Hort., 557: 349-356.

Wünsche, J.N., Bowen, J., Ferguson, I., Woolf, A. \& McGhie, T. (2004): Sunburn on apples. Causes and control mechanisms. Acta Hort., 636: 631-636.

Wünsche, J.N. \& Lakso, A.N. (2000): Apple tree physiology Implications for orchard and tree management. Compact Fruit Tree, 33 (3): 82-88.
Yuri, J.A., Lepe, V., Moggia, C., Bastias, R. \& Bertschinger, L. (2004): Sonnenbrand beim Apfel [Sunburn on apple]. Schweiz. Zeitschr. Obst-Weinbau, (8): 7-10. (In German)

Yuri, J.A., Lepe, V., Sepulveda, A., Bastias, R., Moggia, C., Gonzalez, J.R., Lobos, G.A. \& Glenn, D.M. (2008): Sunburn on apples: Fifteen years of research in Chile supports heat as the main cause of damage. HortScience, 43 (4): 1110-1111. (Abstr.)

Yuri, J.A., Torres, C., Vázquez, J. \& Vázquez, J.L. (1996): Golpe de sol. La Experiencia Chileana, 75-101, In: Yuri, J.A., Moggia, C., Torres, C. (eds.). Coloquio en Pomáceas: Golpe de sol, machucón, escaldado. Centro de Pomáceas. Univ. de Talca. $101 \mathrm{p}$. 